\title{
An Error Analysis on Student's Translation Text
}

\author{
Dina Merris Maya Sari \\ STKIP PGRI Sidoarjo, Indonesia \\ Email: merrisdina1@gmail.com
}

\section{E-ISSN : $2579-4574$}

P-ISSN : 2549-7359

\begin{abstract}
The ability to translate is a language skill that have to be mastered. A foreign language learner must have the ability to translate both verbally and written. This study aims to describe the level of students' error in translating text. The qualitative research approach is used to describe the level of students' error in translating text. The technique of data collection is done in two ways, namely observation and written documents. Data processing includes the activities of identifying and categorizing data, exposuring and interpretating of problems and drawing conclusions. The stage of writing report includes writing report activities and presenting the results. The results show that students make errors in terms of vocabulary, use of prepositions, and incomplete sentences. Error analysis can also be implemented in teaching translation through five stages, namely test, correction, discussion, revision, and evaluation.
\end{abstract}

Keywords: Error Analysis, Translation Text, English Foreign Language, Applied Linguistics

\section{https://ojs.unm.ac.id/eralingua}

\section{INTRODUCTION}

Learning Foreign Language is a process for mastering foreign language in addition to mother tongue or certain regional languages. English is still a foreign language for learners in Indonesia, which until now the learning process is still ongoing and continuous. The expected result of foreign language learning is that students can master the foreign language both verbally and written. Mastery oral and written can be applied in everyday life and can be used as a habit. But in reality, there are many obstacles and problems that are often faced by both students and teachers/lecturers in the learning process (Yusri et all., 2018; Yusri et all., 2018; Romadloni et all., 2017).

Translation is the process of transferring written messages from native language to the target language. Those two languages involved in it certainly have different sentence patterns or grammar. A translator should have good qualifications in understanding language, both the native language and the target language. In translating a written text, there are intralinguistic and extralinguistic factors that must be understood before the ideas of a writer are transferred to the target language. Language -as an object of translation- is part of culture, therefore translating from one language to another cannot be done adequately without having a good knowledge of the culture and structure of those two languages (Longinovic, 2002; Joyce, 2018; Ying et all., 2018; Mohammad et all., 2018).

A translation result is influenced by some factors, namely: (1)writing style (language characteristics) in native language; (2) norms in native language, both in 
the use of grammar and lexical for various texts; (3)cultural problems underlying the native language; (4)setting of text in native language is influenced by tradition when the text is written; (5)estimates of readers who guess based on their knowledge of the topic and the style of language; (6)target or reader language conventions differ from source languages; (7)target language culture is different from native language culture; (8)setting of the target language is influenced by habits at the time of translation; (9) what is explained or discussed depends on the translator's reference; (10) translator's views and prejudices which may be personal, subjective or interpreter interpretations. In addition, it may also be influenced by social and cultural, political, ethnic, religious or religious beliefs, social class, gender, and others (Merç, 2019; Shadiev \& Huang, 2019; Dai, 2019; Melis \& Albir, 2001).

Procedure text is a text that conveying a process of use or create something, which is contained in several stages. The recipe for the process of making food is one example of the procedure text. The translation results from students to translate a recipe into English will be used as data in this study. Students who get the practice of translating a text often find problems or difficulties in transferring the language. The error occurs in the transfer of the message. Error analysis carried out in this study is expected to give contribution for students and teachers/lecturers, especially in conducting the translation process.

\section{LITERATURE REVIEW}

\section{Error Analysis}

Topic related error analysis approach in foreign language teaching had been conducted by previous researchers (Tonapa et all., 2018; Mantasiah et all., 2019; Yusri, 2016; Herlin et all., 2018; Sitanggang et all., 2018). Generally, there are two main views in the study of error analysis, namely contrastive error analysis and nonconstructive error analysis. The approach of contrastive error analysis considers that the mistakes of second language learners arise because of the interference of the first language. In this case, learning is seen as a habituation process that is formed by means of reinforcement where the learning process takes place. Therefore, errors are seen as an incorrect response from a stimulus and must be corrected immediately when it occurs. If the error is not immediately corrected immediately it will become a habit and pattern of wrong behavior that will continue to be stored in the learner's mind. Here, a learner will bring the old habits of the first language and put them in a second language. This certainly results in failure to acquire systems and habits in the second language. In short, it can be said that language learning is a formation of language habits. Contrastive analysis assumed that error derives exclusively from first language interference (Lenon, 2008). In this case, negative transfer or interference occurs when the system in the target language and source language is very different.

The second approach is non-constructive error analysis to see errors in learning a second language from a psychological point of view. In this approach, errors that occur in second language learning are mainly not because of the influence of first language intervention, but there are other factors that occur in second language learning. Developmental errors and intralingual errors as a different category of errors (Richards, 1974). Intralingual errors are errors that 
affect the general characteristics of learning rules, while intralingual errors are errors that arise from the limited knowledge of languages that have in class or textbooks.

The errors between languages and development errors into four categories, namely:

1. Overgeneralization, namely the use of strategies or rules that have been studied before in a new situation. In this case, lessons received previously were applied in the new lesson. For example: see seed [saw]

2. Neglecting the constraints of rules, namely failure to understand the rules or rules of language so that they are applied in contexts that are not appropriate. For example: the man who i saw him

3. Application of incomplete rules, namely the emergence of deviant structures that represent the level of development of language rules needed to produce acceptable speeches. For example: when come you? when did you come?

4. Hypothesis of the wrong concept that is deviation that occurs because of wrong knowledge about the rules of the second language. The example: he is speaking French.

\section{Translation}

Translation is a process of replacing or transferring messages, thoughts, ideas, meaning or information from the source language to the target language. The main point in the translation is that a translator may not change the meaning of the message of the original text. Translation is an activity that needs substantial cultural knowledge (Olk, 2003). Thus, metaphors present problems in translation. In translating authentic material such as English magazines or newspaper articles, translator must have cultural knowledge about English culture. The process of translation consists of three steps (Suryawinata \& Hariyanto, 2003), as follows:

a. Analysis of Source Language Text

Every translation activity starts by analyzing the source language text, because the translator always meets the source language at the first time. To know the message of the source language, the translator must read it, and then the translator will understand the text content. The analysis of source language covers many aspects like sentences, clauses, phrases, and words. The other purpose is to help the translator to change the complex sentence into the simple sentence.

b. The Transference of Message

After the translator can understand the meaning and the structure of the source language text, they can catch the content message. The next step is to transfer the content, the meaning, and the message of the source language into the target language. In this step, the translator must find the meaning of the source language words

c. Restructuration

Restructuration is the process of transforming the source language message into a proper stylist form in the target language, so in this step, the translator must pay attention to the language style in order to fix the language style that is 
appropriate with the text type, and they also must consider to whom the translation is made.

Then, the translator will deal with many problems of meaning, such as lexical meaning, grammatical meaning, contextual meaning, textual meaning, and sociocultural meaning.

a. Lexical Meaning

Lexical meaning is a meaning which is mentioned in the dictionary. Lexical meanings of words are out of the context. For example, The English word 'bad' may mean jahat, buruk, jelek, susah, tidak enak and busuk in Indonesian.

b. Grammatical Meaning

Grammatical meaning is the relationship of the parts of language in the wider units, for example the relationship between word and the other words in a phrase or clause. Example: They can the fish. (can means 'memasukkan dalam kaleng' and function as a predicate.)

c. Contextual Meaning

Contextual meaning is the relationship between the utterances and the situation where the utterances are used. In other words, contextual meaning is a meaning that is correlated with the situation where the language is used. Example: "Good morning!" The utterance might have two meanings, the first meaning is "selamat pagi", but it can mean "keluar" if it is said by a leader to the officers who come late.

d. Textual Meaning

Textual meaning is related to the context of a text. It is found in a discourse or a text. For example, the word 'morphology' in the science of Biology means 'the scientific study of the form and structure of animals and plants,' whereas in Linguistics, the word means 'study of the morphemes of a language and how they are combined to make words.'

e. Socio-cultural Meaning

Socio-cultural meaning is meaning which is closely related to the social situation, and cultural background of the language users. Example: A friend is walking in front of A's house.

A: "Where do you want to go?"

B: "I want to go there, what are you doing?"

A: "I am gardening. Come here"

B:" Thank you. It's already afternoon"

\section{RESEARCH METHOD}

This research is a qualitative using language error analysis approach . In this case the focus of the error analysis is given to the translation errors made by the students when translating the procedure texts from English into Indonesian. Here, the error was analyzed by the error analysis theory in second language learning. This research deals with the fifth semester students of the English Department of STKIP PGRI Sidoarjo. Data collection in this study uses several stages, namely 1) Data search; at this stage the researcher reads the results of the student's translation. The researcher also collects various errors made by students in translating text. 2) Data classification; Data on translation errors that have been 
collected are classified into several groups such as generalization, ignorance of rules, application of incomplete language rules, and hypothesizing incorrect language rules. 3) Categorizing data; at the categorization stage of data, researcher categorizes data into various categories in each data classification such as errors in grammar and errors in meaning.

Analysis of this research data is carried out through the following stages:

1. The recognition stage includes identifying activities errors made by students.

2. The description phase includes characterizing activities on students' errors that have been identified previously.

3. The stage of explanation includes the activity of an explanation of the students' translation text.

4. The evaluation phase includes evaluation of errors in students' translation text

5. The correction stage includes the activity of correcting errors in student translation text

\section{RESULT AND DISCUSSION}

From the results of the error analysis made by the students in translating Indonesian texts into English, two types of errors were found, namely grammatical errors and lexical errors. Lexical errors are the most common mistakes made by the students. This error is in the form of an error in choosing the right words and commensurate with the words in Indonesian language and in accordance with the context of English as the target language.

The second error is related to grammatical errors. This type of error includes errors in the use of prepositions, errors in the use of tenses, and errors in the form of incomplete sentences. More clearly, the types and number of errors made by students can be seen in the following table.

Table 1. Types, Amounts and Percentages of Students' Error

\begin{tabular}{rlcc}
\hline No & Types of Error & Amount & $\%$ \\
\hline $\mathbf{1}$ & \multicolumn{1}{c}{ Lexical Error } & 125 & 7 \\
& & & 5 \\
\hline $\mathbf{2}$ & Grammatical Error & & \\
\hline$\quad$ & a. Preposition Error & 15 & 9 \\
\hline$\quad \begin{array}{l}\text { b. Error in The Use } \\
\text { of Tenses }\end{array}$ & 5 & 3 \\
& $\begin{array}{l}\text { c. Incomplete } \\
\text { Sentence }\end{array}$ & 22 & 1 \\
\hline
\end{tabular}

The table above shows that lexical errors are the most common mistakes made by the students. The number of lexical errors is 125 or $75 \%$ of the total data of 167. The next error is a grammatical error of 42 errors or $25 \%$ of the total errors. Grammatical errors include mis use of prepositions with an amount of 15 errors or $9 \%$ of the total data, use of tenses as many as 5 errors or $3 \%$, and errors due to incomplete sentences of 22 errors or $13 \%$ of the total data. 
Based on table 1 above, it can be seen that students still have difficulty in translating Indonesian texts into English. It indicates that they have not been able to find the exact equivalent of the Indonesian words in English even though they have opened a dictionary. This is related to the lack of students' understanding in the use of English words in accordance with the context and culture.

In addition to lexical errors, grammatical errors are also made by students namely errors in tenses, prepositions, and incomplete sentences. The incompleteness of sentence is the most common error made by the students. It shows the tendency of students to be less able to compose sentences in English. Not only that, the limitation of vocabulary is also one of the reasons that they are unable to make sentences in full. Other grammatical errors show that students do not understand the sentence patterns especially those related to the use of tense and prepositions.

Word selection errors (errors in the lexical field) occur when the students cannot choose the right equivalent to the words in the Indonesian language. It shows that students still have difficulties in determining the right choice of words according to English as the target language. The following is an example of a lexical error made by students:

1. masukkan telur ke dalam mangkok, kocok lepas

a. put an egg into the bowl, stir freely $(X)$

b. add the egg into a bowl, shake off $(X)$

c. crack the egg into the bowl, and beat well (Ö)

The data above shows some lexical errors made by students. In the question, students are asked to translate the phrase "masukkan telur ke dalam mangkok, kocok lepas". The sentence is one example of a sentence in a recipe. To be able to translate the sentence in accordance with the rules in English, it takes the ability of students to determine words that suitable with the culture of British society. This is the problem for most students because the online dictionary does not provide information about cultural suitability. They look difficult to determine the right equivalent.

For example to translate the phrase "masukkan telur ke dalam mangkok, kocok lepas", the students tend to translate words one by one. The word "masukkan", for example, the students translate by the word "put" and "add". In the context of English, to translate the word "masukkan" in the phrase "masukkan telur ke dalam mangkok, kocok lepas" can be used the word "crack" (pecahkan).

Other lexical errors occur when the students translate phrases. The phrase "kocok lepas" in Indonesian is a speech that can be said to be informal. These utterances are usually used in conversational languages and informal writing languages as in food recipes. To translate the phrase "kocok lepas", a cultural understanding is needed to commensurate with the word in English. Therefore, this phrase cannot be translated word by word. The students translate the word "kocok lepas" into "stir freely". The word "stir freely" certainly sounds strange to English speakers and makes the word unacceptable for the word "kocok lepas". Another example of lexical errors from the students is translating the word "kocok lepas" with the word "shake off". The word "shake off" itself means releasing so that it is 
not suitable. It shows that the students still have difficulty in translating words in Indonesian according to the context of English language and culture.

Grammatical errors made by the students in the use of prepositions can be seen in the example below:

2. Masukkan telur ke dalam mangkok, kocok lepas

a. put egg on the bowl, mix it (X)

b. crack the egg into the bowl, and beat well (O)

In the example above, the students make grammatical errors in the form of mis use of prepositions. When translating the clause "masukkan telur ke dalam mangkok" the students translate the word "ke dalam" by the word "on". Here, it can be seen that the students do not yet understand the use of prepositions in English. When translating the word "masukkan" the students should use prepositions "into" not "on". Preposition "into" means "di dalam", whereas preposition "on" means "di atas". Thus, the correct translation in English for the "masukkan telur ke dalam mangkok" clause is "crack the egg into the bowl". In addition, the students also make grammatical errors in using tense as in the example below:

3. Panaskan mentega ke dalam wajan, dan tunggu sampai mendidih bergelembung

a. Heated the butter on pan, wait until boiled $(X)$

b. Heat the butter on pan, wait until it bubbles (Ö)

In the grammatical error above, it can be seen that the students make errors related to the use of tense. When translating the word "panaskan" in the clause "panaskan mentega ke dalam wajan", the students use the word "heated" in the form of past tense. They should use the present tense form, namely "heat". In this case, the sentence is a command sentence. The sentence "panaskan mentega ke dalam wajan" is a command sentence because it is a clue that indicating a command.

Another grammatical error made by the students is incompleteness in making sentences. In this case, making a sentence in English but there is one element of the sentence that is missing or the sentence is not finished. The following is an example of grammatical errors due to incomplete sentences.

a. Setelah kedua sisi roti matang, angkat dan sajikan

a. After both sides of bread cooked, remove and serve (X)

b. After both sides of bread are cooked, remove and serve (Ö)

Grammatical errors in the form of incomplete sentences are also carried out by the students. In this case, they make the incomplete sentence and lacking one element of the sentence. For example in the data above, when translating the word "matang", the students only use the word "cooked". The word "matang" is an adjective. Therefore, when the word becomes the predicate of the sentence, it must be added "to be" before the adjectives. In the sentence "setelah kedua sisi roti matang", the phrase "kedua sisi roti" is the subject and the word "matang" is a predicate. Thus, before the word "matang", the adjective must be added to be "are", so the correct translation for the sentence "setelah kedua sisi roti matang" is "after both sides of bread are cooked" 
The incompleteness of the sentence made by the students indicates that the students do not fully understand the use of adjectives in English. This is influenced by their habit of making sentences in Indonesian. Because in Indonesian questions, adjectives can immediately become a title, so the students apply the rule in English. Thus, when making a sentence with an adjective, they do not add "to be" before the adjective. This finding is similiar with the previos studies conducted by Brown et all. (2019), Incera \& McLennan (2018), Fieder et all. (2019), Brooks \& Kempe (2019) who consider that interference is one of factors which can affect negatively to the language acquisition in foreign language learning. One of factors which can cause interference problem is students do not fully understand the foreign language or second language studied.

\section{CONCLUSION}

Based on the analysis of errors made by the students when translating Indonesian recipes into English, it can be concluded that the students make two types of errors, namely lexical errors and grammatical errors. Lexical errors are related to errors in determining the equivalent of the Indonesian words in English words that are appropriate in the context of English language and culture. Grammatical errors include missing in the use of tense, missing in the use of prepositions, and errors due to incomplete sentences. Errors made by the students indicate that the students still have flaws in terms of determining diction (word selection) in English correctly and lack of understanding of grammatical rules in English.

\section{REFERENCES}

Brooks, P. J., \& Kempe, V. (2019). More Is More in Language Learning: Reconsidering the Less-Is-More Hypothesis. Language Learning, 69, $13-41$.

Brown, B. A., Donovan, B., \& Wild, A. (2019). Language and cognitive interference: How using complex scientific language limits cognitive performance. Science Education, 103(4), 750-769.

Dai, L. (2019, May). The Language Used for Teaching Translation Theory Courses on Master Programs in Translation and Interpreting. In 2019 International Conference on Pedagogy, Communication and Sociology (ICPCS 2019). Atlantis Press.

Fieder, N., Wartenburger, I., \& Rahman, R. A. (2019). A close call: Interference from semantic neighbourhood density and similarity in language production. Memory \& cognition, 47(1), 145-168.

Herlin, H., Azizah, L., \& Fathimah, S. (2018). ANALISIS KESALAHAN MENYUSUN KALIMAT BAHASA JERMAN. Eralingua: Jurnal Pendidikan Bahasa Asing dan Sastra, 2(2).

Incera, S., \& McLennan, C. T. (2018). The time course of within and betweenlanguage interference in bilinguals. International Journal of Bilingualism, 22(1), 88-99. 
Joyce, P. (2018). L2 vocabulary learning and testing: The use of $L 1$ translation versus L2 definition. The Language Learning Journal, 46(3), 217-227.

Lenon, P. (2008). Contrastive Analysis, Error Analysis, Interlanguage. Bielefeld, 51-60. Longinovic, T. Z. (2002). Fearful Asymmetries : A Manifesto of Cultural Translation. Midwest Modern Language Association, 35 (2), 5-12.

Mantasiah, R., Amir, A., Yusri, Y., \& Anwar, M. (2019). ANALISIS PEMAHAMAN MAHASISWA DALAM MATA KULIAH STRUKTUREN UND WORTSCHATZ II DITINJAU DARI ASPEK PERSEPSI. Indonesian Journal of Educational Studies, 22(1).

Melis, N. M., \& Albir, A. H. (2001). Assessment in Translation Studies : Research Needs. Meta, 46 (2), 272-287.

Merç, A. (2019). L1 to L2 Translation Practices in Foreign Language Teacher Education: Student Teachers' Views. Journal of International Cooperation and Development, 2(1), 10-21.

Mohammad, N., Masum, R., Ali, Z., \& Baksh, K. (2018). Teaching practices of English language in the schools of Lasbela District, Pakistan. International Journal of Experiential Learning \& Case Studies, 2(2), 34-39

Olk, H. (2003). Cultural Knowledge in Translation. ELT Journal.

Richards, J. (1974). Error Analysis : Perspectives on Second Language Acquisition. New York: Longman.

Romadloni, A., \& Mantasiah, R. Intercultural approach in foreign language learning to improve students' motivation. Senior Editors, 61.

Shadiev, R., \& Huang, Y. M. (2019). Investigating student attention, meditation, cognitive load, and satisfaction during lectures in a foreign language supported by speech-enabled language translation. Computer Assisted Language Learning, 1-26.

Sitanggang, S. M., Fatimah, S., \& Saud, S. (2018). ANALISIS KESALAHAN DALAM MENGGUNAKAN POSSESIVEPRONOMEN BAHASA JERMAN. Eralingua: Jurnal Pendidikan Bahasa Asing dan Sastra, 2(1).

Suryawinata, Z., \& Hariyanto, S. (2003). Translation : Bahasan Teori dan Penuntun Praktis Menerjemahkan. Yogyakarta: Kanisius.

Tonapa, Y., Anwar, M., \& Mantasiah, R. (2018). Analisis Kesalahan Penggunaan Deiksis dalam Karangan Sederhana Bahasa Jerman. Eralingua: Jurnal Pendidikan Bahasa Asing dan Sastra, 2(1).

Ying, B. T., Hoon, A. L., Halim, H. A., \& Majtanova, M. (2018). Students' beliefs on translation strategy in learning German language. GEMA Online ${ }^{\circledR}$ Journal of Language Studies, 18(1).

Yusri, Y. (2016). Kesalahan Pembentukan Komposita Nomina Dalam Bahasa Jerman Oleh Mahasiswa Program Studi Pendidikan Bahasa Jerman Fakultas Bahasa Dan Sastra Universitas Negeri Makassar. Jurnal Nalar Pendidikan, 4(1). 
Yusri, Y., Mantasiah, R., \& Jufri, J. (2018). The Use Of Two Stay Two Stray Model in English Teaching to Increase Student's Learning Outcome. Journal of Advanced English Studies, 1(1), 39-43.

Yusri, Y., Rosida, A., Jufri, J., \& Mantasiah, R. (2018). Efektivitas Penggunaan Media Youtube Berbasis Various Approaches dalam Meningkatkan Motivasi Belajar Bahasa Inggris. Eralingua: Jurnal Pendidikan Bahasa Asing dan Sastra, 2(2). 